\title{
Different Phenotypes in Dysferlinopathy
}

Key words: dysferlin, limb-girdle muscular dystrophy, Miyoshi myopathy

Limb-girdle muscular dystrophy (LGMD) is a heterogeneous group of disorders and consists of 9 autosomal recessive types (1-9), and 5 autosomal dominant types $(10,11)$.

Recently two different clinical forms of muscular dystrophy, LGMD2B and Miyoshi myopathy have been shown to have a dysferlin defect (12-14), which is a protein of approximately $230 \mathrm{kDa}$, and is located in the muscle plasma membrane. The clinical features of LGMD 2B are characterized by difficulty with running and climbing stairs at the onset of this disorder because of early involvement of the posterior muscle compartment of the thighs and legs, and the shoulder and upper limb muscles become involved later. Miyoshi myopathy was first described by Miyoshi et al (15) in Japanese families in 1986. Miyoshi myopathy is an autosomal recessive distal muscular dystrophy characterized by difficulty with standing on the toes due to weakness of the soleus and gastrocnemius muscles in the posterior compartment of the legs initially and characterized by very high serum $\mathrm{CK}$. In the early phase if you take the skeletal muscle CT scan, the paraspinal muscles are also involved which may explain the high serum CK up to 5,000 IU/l in many cases. Though the above 2 disorders are quite different in clinical phenotypes, they are found to lack dysferlin, and the term dysferlinopathy was made.

Ueyama et al (16) studied 74 dysferlinopathy patients with known dysferlin gene mutations and divided them into four subtypes according to the initial distribution of muscle involvement; 1) limb-girdle muscular dystrophy $2 \mathrm{~B}(56.8 \%), 2)$ Miyoshi myopathy $(32.4 \%), 3$ ) distal anterior compartment type (6.8\%), and 4) scapuloperoneal type (1.4\%).

\section{See also p 532.}

However, they were not able to detect any specific genotype-phenotype correlation. They concluded that there may be an unkown factor other than the dysferlin gene causing clinical heterogeneity in dysferlinopathy. Other investigators subdivide dysferlinopathy into 3 groups: LGMD 2B, Miyoshi myopathy, and hyper-CKemia. At present, the different clinical presentations in dysferlinopathy cannot be explained. Dysferlin is located in the muscle plasma membrane; dysferlin is likely necessary to maintain the structural integrity of the muscle fiber plasma membrane, and lack of dysferlin may cause plasma membrane injury as an early event which eventually causes muscle damage (17). The problem remaining to be solved is that the lack of dysferlin causes proximal muscle weakness in some cases, while it causes distal muscle weakness in others.

Teruyuki KURIHARA, MD The Fourth Department of Internal Medicine, Toho University School of Medicine, 2-17-6 Ohashi, Meguro-ku, Tokyo 153-8515

\section{References}

1) Kloepher HW, Talley C. Autosomal recessive inheritance of Duchenne type muscular dystrophy. Ann Hum Genet 22: 138-143, 1958.

2) Matsumura K, Tomè FM, Collin $\mathrm{H}$, et al. Deficiency of the $50 \mathrm{~K}$ dystrophin associated glycoprotein in severe childhood autosomal recessive muscular dystrophy. Nature 359: 320-322, 1992.

3) Roberds SL, Leturcq F, Allamand V, et al. Missense mutations in the adhalin gene linked autosomal recessive muscular dystrophy. Cell 78: 625-633, 1994.

4) Bönnemann CG, Modi R, Noguchi S, et al. Beta-sarcoglycan (A3b) mutations cause autosomal recessive muscular dystrophy with loss of the sarcoglycan complex. Nat Genet 11: 266-273, 1995 (published erratum appears in Nat Genet 12:110, 1996).

5) Noguchi S, McNally EM, Othmane B, et al. Mutations in dystrophinassociated protein $\gamma$-sarcoglycan in chromosome 13 muscular dystrophy. Science 270: 819-822, 1995 (see comments).

6) Nigro V, de Sá Moreira E, Piluso G, et al. Autosomal recessive limbgirdle muscular dystrophy, LGMD 2F, is caused by a mutation in the $\delta$ sarcoglycan gene. Nat Genet 14: 195-198, 1996.

7) Richard I, Broux O, Allamand V, et al. Mutations in the proteolytic enzyme calpain 3 cause limb-girdle muscular dystrophy type $2 \mathrm{~A}$. Cell 81: $27-40,1995$.

8) Sorimachi H, Toyama-Sorimachi N, Saido TC, et al. Muscle-specific calpain, p94, is degraded by autolysis immediately after translation, resulting in disappearance from muscle. J Biol Chem 268: 10593-10605, 1993.

9) Fardeau M, Eymard B, Mignard C, et al. Chromosome 15-linked limbgirdle muscular dystrophy: Clinical phenotypes in Réunion Island and French metropolitan communities. Neuromuscul Disord 6: 447-453, 1996.

10) Minetti C, Sotgia F, Bruno $C$, et al. Mutations in the caveolin-3 gene cause autosomal dominant limb-girdle muscular dystrophy. Nat Genet 18: 365-368, 1998.

11) Sunada $Y$, Ohi $\mathrm{H}$, Hase A, et al. Transgenic mice expressing mutant caveolin-3 show severe myopathy associated with increased nNOS activity. Hum Mol Genet 10: 173-178, 2001.

12) Liu J, Aoki M, Illa I, et al. Dysferlin, a novel skeletal muscle gene, is mutated in Miyoshi myopathy and limb girdle muscular dystrophy. Nat Genet 20: 31-36, 1998.

13) Matsuda C, Aoki M, Hayashi YK, et al. Dysferlin is a surface membraneassociated protein that is absent in Miyoshi myopathy. Neurology 53: 1119-1122, 1999.

14) Aoki M, Liu J, Richard I, et al. Genomic organization of the dysferlin gene and novel mutations in Miyoshi myopathy. Neurology 57: 271-278, 2001.

15) Miyoshi K, Kawai H, Iwasa M, et al. Autosomal recessive distal muscular dystrophy as a new type progressive muscular dystrophy. Seventeen 
cases in eight families including an autopsied case. Brain 109: 31-54, 1986.

16) Ueyama H, Kumamoto T, Horinouchi H, Fujimoto $S$, Aono H, Tsuda $T$.
Clinical heterogeneity in dysferlinopathy. Intern Med 41: 532-536, 2002. 17) Selcen D, Stilling G, Engel AG. The earliest pathologic alterations in dysferlinopathy. Neurology 56: 1472-1481, 2001. 